\section{Densidade Relativa de uma Solução. Desmistificando Conceitos}

\section{Prezada Editora,}

Os anestesiologistas controlam o nível da analgesia espinal com ajuda da densidade relativa, pelo fato do anestésico local ser mais ou menos denso comparado com o líquido cefalorraquidiano (LCR).

Diversos termos (massa específica ou densidade absoluta, peso específico, densidade relativa) são freqüentemente usados e inter-relacionados para descrever as características das soluções dos anestésicos utilizados para raquianestesia. Portanto, é importante definirmos o que são: densidade absoluta, peso específico e densidade relativa. Densidade absoluta $(\rho)$ de uma substância é o quociente da massa $(\mathrm{m})$ de uma porção de substância pelo volume (V) que ela ocupa. Peso específico $(\delta)$ de uma substância é a razão do peso $(P)$ de uma porção dessa substância pelo volume (V) que ela ocupa. Densidade relativa é a razão da massa específica (densidade absoluta) de uma substância pela massa específica de outra substância tomada como referência. Dessa forma, a densidade relativa é um número puro (grandeza adimensional). Ao se afirmar que o mercúrio é mais pesado (mais denso) que a água, isso quer dizer que um certo volume de mercúrio é mais pesado que um igual volume de água e, assim, podemos referir que a densidade relativa é o número de vezes que uma substância é mais pesada que igual volume de água, considerando-se a mesma aceleração da gravidade (a densidade relativa também pode ser escrita como: $d=P / P_{\circ}-$ quando os corpos têm volumes iguais, sendo $\mathrm{P}_{\circ}$ o peso da substância referência).

A densidade absoluta tem por unidade, no Sistema Internacional de Unidades (SI), o kilograma por metro cúbico $(\mathrm{kg} /$ $\mathrm{m}^{3}$ ). São usadas também outras unidades, como o grama por centímetro cúbico $\left(\mathrm{g} / \mathrm{cm}^{3}\right)$ e o kilograma por litro $(\mathrm{kg} / \mathrm{L})$. Essas unidades são assim padronizadas, pois trabalhamos com matérias em diferentes estados físicos: sólido, líquido e gasoso.

Geralmente, a densidade relativa dos sólidos e líquidos é definida em relação à água a $4^{\circ} \mathrm{C}$ (densidade absoluta da água a $\left.4^{\circ} \mathrm{C}=1 \mathrm{~g} / \mathrm{cm}^{3}=1 \mathrm{~kg} / \mathrm{L}=10^{3} \mathrm{~kg} / \mathrm{m}^{3}\right)$. Logicamente, é possível tomar outros padrões de referência que não a água. A densidade relativa dos gases é, comumente, referida em relação ao oxigênio.

Acreditamos que para entender as dispersões das diversas soluções dos anestésicos locais, o correto seria compararmos as duas densidades relativas (anestésico e LCR). Para isso, as empresas deveriam dizer as densidades relativas dos anestésicos (comparativamente à água a $4^{\circ} \mathrm{C}$ ), logicamente tomando o LCR como a $37^{\circ} \mathrm{C}$. Assim, podemos observar os seus valores e afirmarmos que uma delas apresenta ou não uma densidade relativa maior que a outra. $O$ termo baricidade não é muito adequado, já que o mesmo dá idéia de pressão (observe que a massa específica de um gás varia consideravelmente com a pressão, mas não a massa específica de um líquido, ou seja, gases são facilmente compressíveis, mas líquidos não. Assim, o termo seria mais bem aplicado ao estudo dos gases).

Para que pudéssemos entender definitivamente a dispersão das diferentes soluções dos anestésicos locais, seria importante que a indústria disponibilizasse a densidade relativa do agente anestésico em relação à água a $4^{\circ} \mathrm{C}$ ou em relação ao líquor e em qual temperatura.

Atenciosamente,

Luiz Eduardo Imbelloni, TSA

Marildo A. Gouveia, TSA

Rogean Rodrigues Nunes, TSA - graduando em Engenharia Eletrônica

\section{The Relative Density of a Solution. Unmasking Concepts}

\section{Dear Editor,}

Anesthesiologists control the level of spinal analgesia with the help of the relative density because local anesthetics are more or less dense than the cerebrospinal fluid (CSF).

Several terms (specific mass or absolute density, specific weight, relative density) are frequently used to describe the characteristics of the anesthetic solutions used for spinal anesthesia. Thus, it is important to define the following: absolute density, specific weight, and relative density. The absolute density $(\rho)$ of a solution is the coefficient between the mass (m) of a portion of the substance and the volume (V) that it occupies. The specific weight $(\delta)$ of a substance is the ratio between the weight $(P)$ of a portion of this substance and the volume $(\mathrm{V})$ that it occupies. The relative density is the ratio between the specific mass (absolute density) of a substance and the specific mass of another substance used as reference. Thus, relative density is a pure number (non-dimensional value). Stating that mercury is heavier (more dense) than water means that a certain volume of mercury is heavier than an equal volume of water, and we can say that relative density is the number of times that a substance is heavier than an equal amount of water, considering the same gravity acceleration (the relative density can also be described as: $\mathrm{d}=\mathrm{P} / \mathrm{P}_{\mathrm{o}}$ - when the bodies have the same volume, in which $P_{0}$ is the weight of the reference substance).

The unit of absolute density in the International System of Units (SI) is kilogram per cubic meter $\left(\mathrm{kg} / \mathrm{m}^{3}\right)$. Other units are used also, such as the gram per cubic centimeter $\left(\mathrm{g} / \mathrm{cm}^{3}\right)$, and 
the kilogram per liter $(\mathrm{kg} / \mathrm{L})$. These units are, thus, standardized because we work with substances in different physical states: solid, liquid, and gaseous.

Usually, the relative density of solids and liquids is defined relative to water at $4^{\circ} \mathrm{C}$ (absolute density of water at $4^{\circ} \mathrm{C}=$ $\left.1 \mathrm{~g} / \mathrm{cm}^{3}=1 \mathrm{~kg} / \mathrm{L}=10^{3} \mathrm{~kg} / \mathrm{m}^{3}\right)$. It is possible to use standards of reference other than water. The relative density of gases is usually relative to oxygen.

We believe that to understand the dispersion of the different solutions of local anesthetics, we should compare both relative densities (anesthetics and CSF). Therefore, the pharmaceutical companies would have to provide the relative densities of the anesthetics (relative to water at $4^{\circ} \mathrm{C}$ ); obviously the temperature of the CSF would be $37^{\circ} \mathrm{C}$. Thus, we could observe their values and state that the relative density of one of them is greater than the other. The term baricity is not very adequate, because it gives the idea of pressure. (Note that the specific mass of a gas varies considerably with pressure, but not the specific mass of a liquid, i.e., gases are easily compressible, but not fluids. Therefore, this term would be better used for gases.)
To understand definitively the dispersion of the different solutions of local anesthetics, it would be important that the pharmaceutical industry provided us with their relative density relative to water at $4^{\circ} \mathrm{C}$ or to the spinal fluid and the temperature.

Sincerely,

\author{
Luiz Eduardo Imbelloni, TSA, M.D. \\ Marildo A Gouveia, TSA, M.D. \\ Rogean Rodrigues Nunes, TSA — graduate \\ student in Electronic Engineering \\ REFERÊNCIAS - REFERENCES
}

01. Halliday D, Resnick R, Walker R - Fundamentos de Física, $6^{\mathrm{a}}$ Ed, Rio de Janeiro, LTC, 2002;v.2;48-49.

02. Calçada CS, Sampaio JL - Física Clássica: Termologia, Fluidomecânica e Análise Dimensional, $2^{a}$ Ed, São Paulo, Editora Atual, 1998;1-2.

03. Serway RA - Física para Cientistas e Engenheiros, $3^{\mathrm{a}}$ Ed, Rio de Janeiro, LTC, 1996;332-333. 